\section{Fiscaoeconomia}

E-ISSN: 2564-7504

2021, Volume 5, Issue 2, 595-610

https://dergipark.org.tr/tr/pub/fsecon
Research Article/Araştırma Makalesi

Submitted/Geliş: 05.03.2021

Accepted/Kabul: 29.04.2021

Doi: $10.25295 /$ fsecon.891839

\title{
Endogenous Money Supply: Turkish Economy (2011-2018)
}

İcsel Para Arzı: Türkiye Ekonomisi (2011-2018)

\section{Leyla BAŞTAV ${ }^{1}$}

\begin{abstract}
There are two answers to the question of how money is created: according to the exogenous money hypothesis central banks have full control over the money stock in the markets and other policy instruments; whereas endogenous money theory stipulates money is created by credit demand of economic actors. Demand for credits in turn emanates from the production process of firms, triggered by changes in the production costs, basicly by a rise in nominal wages. This paper aims to analyze whether money supply creation is endogenous in Turkish money markets during the period 2011-2018 by monthly data, for which cointegration between money supply (money base, M1, M2) and credits is tested by Johansen method and VECM is estimated for specifying direction of causality between the variables. As a robustness check of the causality obtained from VECM long and short run analysis, cpi inflation is added to the model and a four variate Toda Yamamoto VAR is estimated. Results point at causality from credits to money supply and that credits extended by banks form basis of the money supply.
\end{abstract}

Jel Codes: E12, E51, C32

Keywords: Post Keynesian Economics, Endogenous Money, Johansen Cointegration Test, VECM, Toda Yamamoto

\footnotetext{
${ }^{1}$ Dr., Banking Regulation Supervision Agency (Rtd.), Bastav06@yahoo.com.tr, ORCID 0000-0003-1533-2289
}

Citation/Atıf: Baştav, L. (2021). Endogenous money supply: Turkish economy (2011-2018). Fiscaoeconomia, 5(2), 595-610. doi: 10.25295/fsecon.891839 
Baştav, L. (2021). Endogenous money supply: Turkish economy (2011-2018).

Fiscaoeconomia, 5(2), 595-610. doi: 10.25295/fsecon.891839

\section{Öz}

İktisadi teoride paranın nasıl yaratıldığı sorusuna iki farklı cevap bulunmaktadır: dışsal para hipotezine göre merkez bankalarının para stoku ve diğer para politikası araçları üzerinde tam kontrolü bulunmaktayken; içsel para teorisine göre para ekonomik aktörlerin kredi talebi üzerine yaratılmaktadır. İçsel para teorisine göre para talebi firma üretim süreçlerinden ortaya çıkmakta, üretim maliyetlerindeki artış ve daha çok da nominal ücretlerdeki artıştan kaynaklanmaktadır. Bu çalışmada aylık veri kullanılarak 2011-2018 arasındaki dönemde para arzının içselliği araştırılmakta; para arzı M1, M2 ile krediler arasında Johansen eşbütünleşme ilişkisi olup olmadığı sınanarak, VECM analizi ile değişkenler arasındaki nedensellik sorgulanmaktadır. Buna ilave olarak VECM kısa ve uzun dönem nedensellik testi sonuçlarının güçlü olup olmadığı tüfe enflasyon değişkeni ilave edilerek Toda Yamamoto testiyle sınanmaktadır. Elde edilen sonuçlara göre nedensellik kredilerden para arzına doğrudur; para arzı içsel olup talep tarafından belirlenmekte, banka kredileri para arzının temelini oluşturmaktadır.

Jel Kodları: E12, E51, C32

Anahtar Kelimeler: Post Keynesyen Ekonomi, Içsel Para Arzı, Johansen Eşbütünleşme Testi, VECM, Toda Yamamoto

\section{Introduction}

There is hardly any consensus about money creation in economic theory, which is defined alternatively by two schools of thought. According to Monetarists and Neoclassics money is exogenously created, by central banks and there is a stable money multiplier; whereas Post Keynesians provide that commercial banks financing the private sector actively create money through the production process and that money is endogenous. Endogenous money hypothesis provides that level of money stock in the economy is determined by the credit demand which is in turn determined by the factor variables determining the level of production.

Since rise of the Monetarist school following A. Schwartz and M. Friedman's infamous "Monetary History of the United States" and Friedman's AEA speech in 1967; exogenous money created by the central banks has been treated as the main policy instrument in macroeconomics. Monetarists have attributed major role to monetary policy in dealing with the business cycles, and in fine tuning growth and inflation. Up until the 1990s Monetarist views have dominated mainstream economics with Keynesians also recognizing the importance of money stock as policy instrument. During the time central banks have heavily leaned on monetary policy against the swings caused by business cycles.

Starting with Tobin (1971) critics have started raising their voice against the exogeneity of money claiming that commercial banks and households are the actual actors in money creation as opposed to the view that money is created centrally by the monetary authority. Writers like Moore (1979), Kaldor (1985) have built basics of the approach advocating that money growth is created by the financial system, and that it cannot be controlled by central banks. Views have gathered strength during and after the 1990s and today Post-Keynesians refute causality from money supply to prices saying that price increases raise financing needs 
Baştav, L. (2021). Endogenous money supply: Turkish economy (2011-2018).

Fiscaoeconomia, 5(2), 595-610. doi: 10.25295/fsecon.891839

of firms who increase credit demand from banks to finance production process, thereby triggering deposits opened in the banking system. This is how money creation is realized in the financial system where central banks have only assumed a passive role.

Arguments between two opposing views have received considerable attention by empiricists and research has been conducted for various countries and various periods. In the course of argumentative work, alternative mechanisms within the financial system have been described gathering under the titles accomodationist, structuralist and liquidity approaches according to the role attributed to central banks in money creation and determination of interest rates.

Motivated by the arguments between different lines of thought, we examine the recent money creation mechanism in Turkey, using the Johansen cointegration test and Vector Error Correction Model (VECM). The main argument is represented by existence of long-run relationship between money supply variables and credits and the direction of causality from credits to money. Additionally, the causal relation between bank loans and money is tested by a four variate Toda Yamamoto (TY) VAR model to check robustness of results obtained in the cointegration and VECM to specify direction of causality between the variables. Additional cpi variable has been integrated into the Toda Yamamoto model which has crucial theoretical implications Results of the Toda Yamamoto analysis support VECM estimation results that causality goes from credits to money supply, i.e. money creation is endogenous, and provide that the Central Bank accommodates for funds demanded by commercial banks, as well as giving evidence about the presence of liquidity preference. Addition of the cpi inflation has provided the important information in favor of the Post Keynesian theory that causality is from prices to money rather than vice versa.

\section{Post Keynesian (PK) Theory}

Following Tobin's ctitical work in 1971, pioneers of Post Keynesian thought: Moore (1979) and Kaldor (1985) have raised arguments against Neoclassic and Monetarist views that money is exogenously created by the central banks; providing their case for endogenous money supply. The endogeneity of money had already been raised by the Banking School as early as beginning of the 19th century when the disciples had money supply defined as created by credit demand of entrepreneurs to finance economic transactions (Wray, 1990: 100). It has been debated in the literature that endogenous money is already implicit in the works of economists like Marx, Schumpeter, Kalecki, Robinson and Wicksell (Fontana, 2003: 291, Wray, 1990: 99).

The main argument raised by Kaldor and Moore was that causality of the relation between the money supply and price level was not by any means from money stock to prices, but the other way round. Post Keynesians provided that there can be no money creation independent of the economic activity, during which economic units would demand credits to finance the production process. Commercial banks extending these new credits would open deposit accounts which would raise the money supply and the monetary base in the economy. Post Keynesians have provided evidence from 1980' monetary policy treatment in the US and UK economies to support their views. The restricted money supply then could not get to prevent inflation and money stock rose incessantly when in the end the FED had to intervene to raise the interest rate to prevent inflation (Kaldor, 1985: 75) . 
Baştav, L. (2021). Endogenous money supply: Turkish economy (2011-2018).

Fiscaoeconomia, 5(2), 595-610. doi: 10.25295/fsecon.891839

According to Moore (1989) and Kaldor (1985) as the banks extend credits to firms, economic agents will open more deposits which will raise reserve requirement of banks. On this account banks will demand funds from discount window of the central bank which the bank will supply with infinite elasticity as lender of last resort. According to the "accommodationist (horizontalist) approach" central bank will determine the discount window rate, playing price setter role in monetary policy. The bank has no control over the monetary base/money stock of the economy however is a price setter in money markets (Lavoie 1992, Rogers, 1989).

The alternative "structuralist view" of Minsky (1982) (and his followers) have described causality running from price level to the money stock and have emphasized importance of the role of credits extended in the financial system. Structuralists have advocated that banks only borrow partially from the central bank for their funding needs, but also self provide reserves by their financial innovative instruments and/or liability management. This way both the credits demanded and monetary base will determine the money supply. As per the view central bank will have some power over the amount of reserves in the system, whereas the interest rate will endogenously be determined in the markets (Howells 1995, Wray 1990: 132).

Liquidity preference approach is sceptic about banks passively accepting the rate of interest set by central banks. Advocates assume that banks' liquidity preferences are determined by their decisions to extend credits and on the profitable investments they envisage. Whenever supply of deposits is below the level of demand for loans, banks will realize investments in a wat that provides equilibrium in the funds market. Although some totally refute the role of liquidity preferences à la Keynes, others put it at the heart of endogenous money view. Notwithstanding the opposing arguments, gist of the view is about who sets the interest rates i.e. whether it is central banks or market actors by their liquidity preferences.

\section{Empirical Studies' Survey}

The pioneering study of Moore (1979) is followed by his 1983 work on the US for the period 1964-1981. Moore (1983: 555) has detected money wages trigger the mechanism of credit creation and therefore money supply is endogenous. The first generation of studies under the name buffer stock mechanism emphasize the effect of rising credit demand of firms as a result of nominal wage increases. Increase in credits would raise deposits opened by firms at the banks, and thereby the money supply. Kaldor (1985) in his seminal work on the UK money markets also has detected endogenous money and that credits cause money supply for the period 1966-1979. Palley's findings (1991) also support endogeneity for the US.

The following generation of work encounters for the long term investments, other expenses of firms etc. as the major factors leading to a rise in credits as in Arestis (1987/1988), Arestis and Mariscal (1995), Howells (1999), Howells and Hussein (1998). Howells and Hussein (1998) have detected endogeneity for G-7 by applying Johansen cointegration and Granger causality tests for the 1957-1993 period.

Panagopoulos and Spiliotis (1998) detected endogenous money for Greece, Vera (2001) similarly for Spain, Lavoie (2005) for Canada. Nayan et al. (2013) for 177 countries with dynamic panel data for the period 1970-2011 have detected endogenous money supply. Badarudin et al. (2013) have also detected money creation inside the financial system, through different sub-periods between 1975-2007 for G-7. Işık et al. (2018) for 13 EU countries 
between 2001-2015 with panel ARDL and Granger causality saw that credits paved the way to money creation

Turkish money markets studies have started by 1990s but research around the subject has exploded during the 2000s. Prominent work in the field follows in Table 1 below.

Table 1: Empirical Studies on Turkey

\begin{tabular}{|c|c|c|c|}
\hline Author(s) & Period & Method & Results \\
\hline $\begin{array}{l}\text { Aybar and } \\
\text { Harris (1998) }\end{array}$ & 1987-1997 & $\begin{array}{c}\text { OLS } \\
\text { Regression }\end{array}$ & $\begin{array}{c}\text { Money is Created Endogeneously as per } \\
\text { the Structuralist Approach }\end{array}$ \\
\hline $\begin{array}{l}\text { Işık (2000, PhD. } \\
\text { Thesis) }\end{array}$ & (1987-1999) & $\begin{array}{l}\text { VAR, Granger } \\
\text { Causality }\end{array}$ & $\begin{array}{l}\text { Total Credits Create Money Supply } \\
\text { (Money Base, M1, M2, M2Y) }\end{array}$ \\
\hline $\begin{array}{l}\text { Çavuşoğlu } \\
\text { (2003) }\end{array}$ & $(1985-2005)$ & Cointegration & Public Sector Deficits Cause Money Supply \\
\hline $\begin{array}{c}\text { Karabulut } \\
(2005)\end{array}$ & $(1986-2004)$ & $\begin{array}{l}\text { Granger } \\
\text { Causality }\end{array}$ & $\begin{array}{l}\text { Total Credits are Casually Related to } \\
\text { Currency in Circulation and M1 }\end{array}$ \\
\hline $\begin{array}{l}\text { Çifter and Özün } \\
\text { (2007) }\end{array}$ & $(1997-2006)$ & Cointegration & $\begin{array}{l}\text { Total Credits Create Money Supply M2, } \\
\text { but not M2Y) }\end{array}$ \\
\hline $\begin{array}{l}\text { Işık and } \\
\text { Kahyaoğlu } \\
(2011)\end{array}$ & $(1987-2007)$ & $\begin{array}{l}\text { Weak } \\
\text { Exogeneity } \\
\text { Tests, VECM }\end{array}$ & $\begin{array}{l}\text { Monetary Base } \\
\text { is Endogenous }\end{array}$ \\
\hline Özgür (2011) & $(1987-2009)$ & $\begin{array}{l}\text { Cointegration, } \\
\text { VECM Analysis }\end{array}$ & $\begin{array}{c}\text { Total Credits Create Money Supply M2, } \\
\text { M3 (but Create M2Y And M3Y Only After } \\
\text { FX Control Variables) }\end{array}$ \\
\hline $\begin{array}{l}\text { Güney and } \\
\text { Çepni (2016) }\end{array}$ & $(2006-2015)$ & $\begin{array}{l}\text { Cointegration, } \\
\text { VECM, } \\
\text { Causality } \\
\text { Analysis }\end{array}$ & $\begin{array}{l}\text { Causality Runs from Credits to Money } \\
\text { Supply }\end{array}$ \\
\hline $\begin{array}{l}\text { Incekara and } \\
\text { Amanov (2017) }\end{array}$ & $(1990-2016)$ & $\begin{array}{l}\text { Cointegration, } \\
\text { VECM } \\
\text { Analysis, } \\
\text { Granger } \\
\end{array}$ & $\begin{array}{c}\text { Central Bank has no Control over the } \\
\text { Monetary Base (no Exogeneous Money } \\
\text { Supply) }\end{array}$ \\
\hline Tayyar (2017) & $(2000-2016)$ & $\begin{array}{c}\text { Toda } \\
\text { Yamamoto } \\
\end{array}$ & Endogenous Money Supply in Turkey \\
\hline Yurtkur (2019) & $(2006-2018)$ & $\begin{array}{c}\text { Toda } \\
\text { Yamamoto, } \\
\text { Bootstrap TY }\end{array}$ & $\begin{array}{c}\text { Causality From Credits To Monetary Base, } \\
\text { Money Multiplier and M3 (Also from M3 } \\
\text { to Credits) }\end{array}$ \\
\hline
\end{tabular}




\section{Data and Methodology}

Data for the study is taken from the Central Bank of Turkey EVDS database for the Monetary Base (MB), money supply $M 2$ and $M 3$ and total bank credits granted to private sector (CR), whereas inflation (CPI) series is from Turkish Institude of Statistics (TÜiK) in monthly frequency, spanning the years between 2011M01 to 2018M06. The particular time in question is picked because it involves a homegenous period in terms of the monetary policy. Money supply variables and total credit demand are in stock values, whereas CPI represents monthly rate of inflation. All variables are transferred to natural logarithms and are expressed with an initial "L" i.e., LMON, LM2, LCR etc. in the text. The descriptive graphs of the series follow in Figure 1 below. Pictorially there is co-movement of the M2, M3 and total credits.

Figure 1: Time Graphs (at log levels, CPI log monthly \% change)

LM3

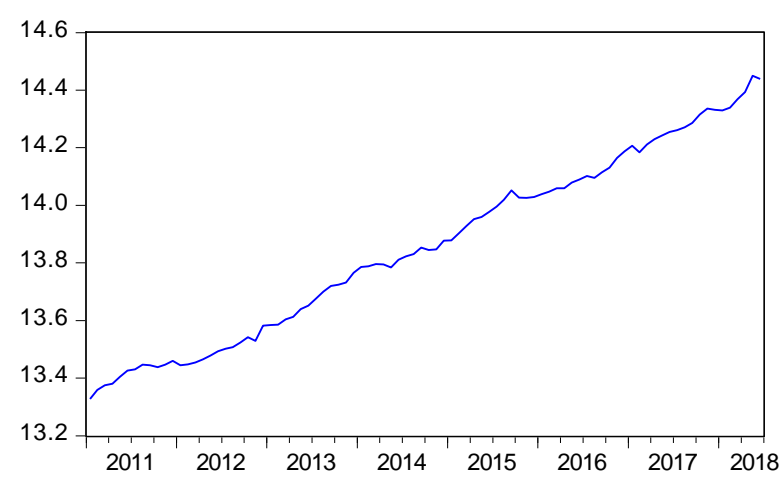

Monetary Base

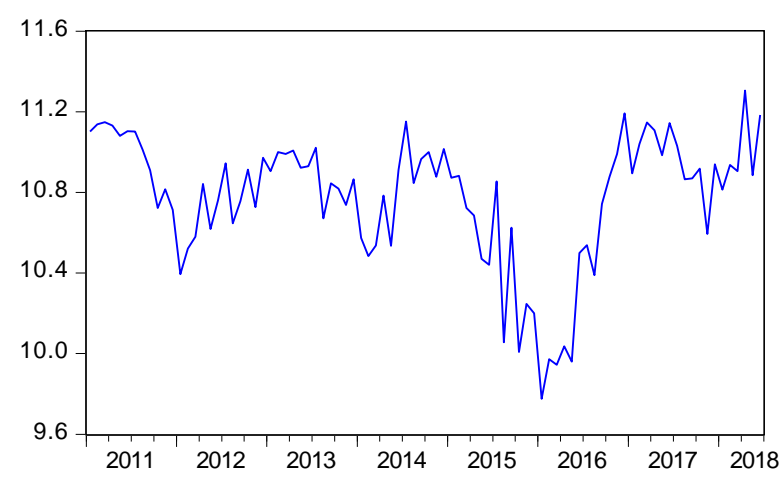

LCPI

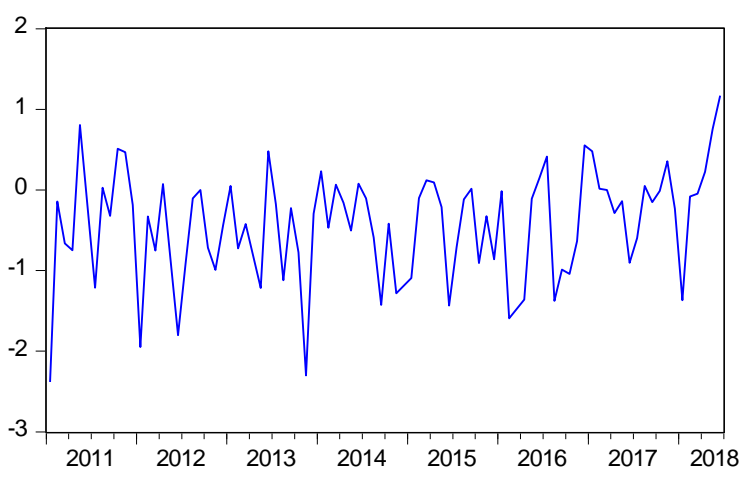

LM2

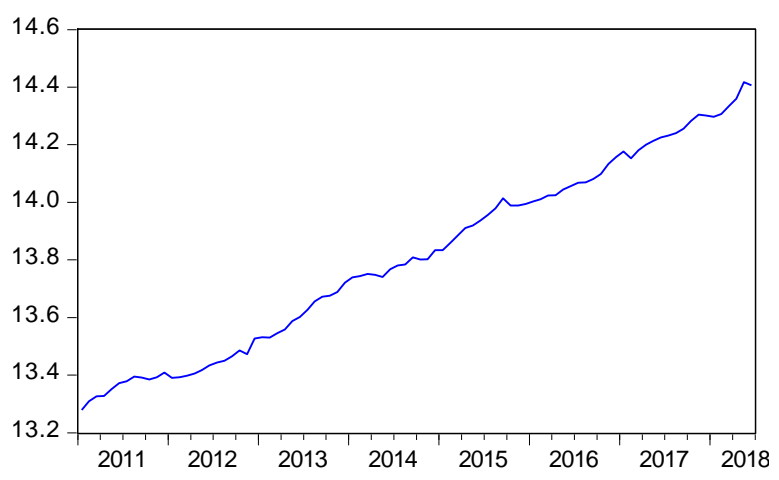

Private Sector Credits

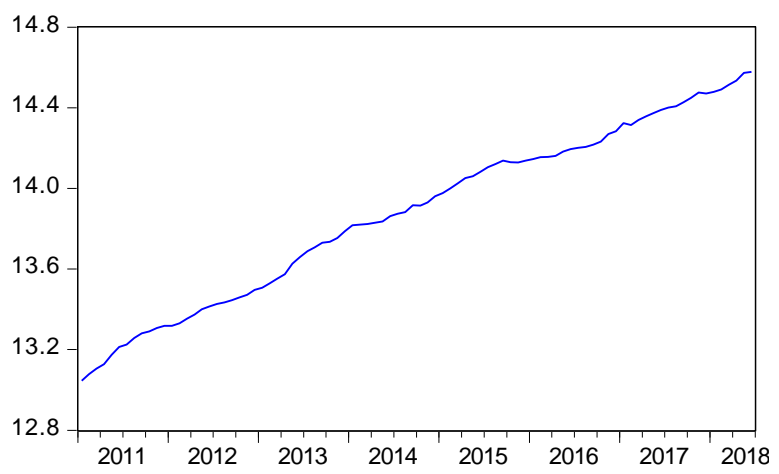


Long-run correlation between money supply and credits will be investigated by Johansen cointegration tests and causality will further be examined by VECM analysis. Before conduct of the Johansen cointegration test, variables are checked for stationarity by the ADF, PP, KPSS unit root tests in Section 4.1 below.

\subsection{Unit Root Tests}

Stationarity of the series are checked by three different tests: Augmented Dickey-Fuller (ADF), Phillips Perron (PP) and Kwiatkowski-Phillips-Schmidt-Shin (KPSS) using Eviews 9 . Results in Table 2 show that there is instability revealed by nonstationarity in the form of a unit root in $M B, M 2, M 3$ and $C R$, however first differences are stationary and that series are integrated of order one, I(1). CPI series is already stationary, integrated at levels, I(0).

Table 2: Unit Root Test Results(1)

\begin{tabular}{|c|c|c|c|c|c|c|}
\hline \multirow[t]{3}{*}{ Variables } & \multicolumn{6}{|c|}{ Test Statistic Values } \\
\hline & \multicolumn{2}{|c|}{ ADF } & \multicolumn{2}{|c|}{ PP } & \multicolumn{2}{|c|}{ KPSS } \\
\hline & $I(0)$ & $I(1)$ & $I(0)$ & $I(1)$ & $I(0)$ & $I(1)$ \\
\hline (LMB) monetary base I(1) & $\begin{array}{c}-2.89 \\
(-2.90)\end{array}$ & $\begin{array}{l}-16.92 \\
(-2.89)\end{array}$ & $\begin{array}{l}-3.42^{(2)} \\
(-3.46)\end{array}$ & $\begin{array}{c}-16.18^{(2)} \\
(-3.46)\end{array}$ & $\begin{array}{c}\mathbf{0 . 1 6} \\
(0.46)\end{array}$ & - \\
\hline (LM2) money supply I(1) & $\begin{array}{c}0.55 \\
(-2.89)\end{array}$ & $\begin{array}{c}-9.80 \\
(-2.89)\end{array}$ & $\begin{array}{c}0.64 \\
(-2.89)\end{array}$ & $\begin{array}{c}-9.81 \\
(-2.89)\end{array}$ & $\begin{array}{c}1.23 \\
(0.46)\end{array}$ & $\begin{array}{c}\mathbf{0 . 1 0} \\
(0.46)\end{array}$ \\
\hline (LM3) money supply I(1) & $\begin{array}{c}0.50 \\
(-2.89)\end{array}$ & $\begin{array}{c}-9.91 \\
(-2.89)\end{array}$ & $\begin{array}{c}0.65 \\
(-2.89)\end{array}$ & $\begin{array}{c}-9.95 \\
(-2.89)\end{array}$ & $\begin{array}{c}1.23 \\
(0.46)\end{array}$ & $\begin{array}{c}\mathbf{0 . 1 0} \\
(0.46)\end{array}$ \\
\hline (LCR) credits I(1) & $\begin{array}{c}-2.34 \\
(-2.89)\end{array}$ & $\begin{array}{l}-7.76 \\
(-2.89)\end{array}$ & $\begin{array}{c}-2.03 \\
(-2.89)\end{array}$ & $\begin{array}{c}-7.83 \\
(-2.89)\end{array}$ & $\begin{array}{c}1.23 \\
(0.46)\end{array}$ & $\begin{array}{c}\mathbf{0 . 3 4} \\
(0.46)\end{array}$ \\
\hline (LCPI) inflation I(0) & $\begin{array}{c}-8.05 \\
(-2.90)\end{array}$ & & $\begin{array}{c}-8.05 \\
(-2.90)\end{array}$ & & $\begin{array}{c}\mathbf{0 . 3 9} \\
(0.46)\end{array}$ & \\
\hline
\end{tabular}

(1) Schwartz Info criterion is used to choose the lag length of ADF test whereas Bartlett Kernal spectral estimation method with Newey-West bandwidth is used for the PP test. Critical values in parantheses. KPSS tests null hypothesis of stationarity. Tests are at 5 percent level of significance. ${ }^{(2)} t$ test with trend.

\subsection{Johansen Test and VECM Analysis}

Johansen cointegration test is conducted for detecting long-run relation between the I(1) money supply variables MB, M2, M3 and total credits whose results follow in Table 3 below. Results of the Johansen test reveal cointegration over the eight year period 2011-2018 where the null hypothesis of no cointegration is rejected at the 5 percent level of significance. Results for number of cointegrating vectors by Johansen test reported in the Table below presenting trace as well as max-eigen statistics with the corresponding critical values. Table reveals 
Baştav, L. (2021). Endogenous money supply: Turkish economy (2011-2018).

Fiscaoeconomia, 5(2), 595-610. doi: 10.25295/fsecon.891839

existence of long-run cointegration between each of the money supply variables and total credits.

Table 3: Johansen Tests for Cointegration ${ }^{(1)}$

\begin{tabular}{|c|c|c|c|c|c|c|c|}
\hline & Lag & $\mathrm{H}_{0}$ & Trace & $\begin{array}{c}\text { Critical } \\
\text { Val 0.05 }\end{array}$ & $\begin{array}{c}\text { Max- } \\
\text { Eigen }\end{array}$ & $\begin{array}{c}\text { Critical } \\
\text { Val 0.05 }\end{array}$ & Cointegration \\
\hline LMB and LCR & 1 & $\mathrm{r}=0^{(2)}$ & 20.92 & 15.5 & 20.84 & 14.26 & YES \\
\hline LM2 and LCR & 1 & $\mathrm{r}=0^{(2)}$ & 21.58 & 15.49 & 21.56 & 14.26 & YES \\
\hline $\begin{array}{c}\text { LM3 and L } \\
\text { CR }\end{array}$ & 1 & $\mathrm{r}=0^{(2)}$ & 20.31 & 15.49 & 20.31 & 14.26 & YES \\
\hline
\end{tabular}

(1) The optimal lag interval is selected by AIC, SC, HQ etc. information criteria.

(2) Rejection of no cointegration hypothesis.

Having fulfilled the cointegrating precondition, VECM model has been estimated for detecting the direction of causality between the variables as in model (1) below.

$$
\Delta y_{t}=\beta_{0}+\sum_{i=1}^{n} \beta_{1 i} \Delta y_{t-i}+\sum_{i=1}^{n} \beta_{2 i} \Delta x_{t-i}+\beta_{3} E C_{t}+\epsilon_{t}
$$

VECM results is provided in Table 4 below. The estimated equations are free from autocorrelation. Accordingly, the error correction term (ECT) in the first, third and fifth rows are negative and significant as expected meaning that the system can correct shocks and return to equilibrium in the long-run. Coefficients indicate the rate at which deviations resulting from non-stationarity are adjusted in the next period, namely next month. Speed of adjustment of monetary base to private sector loans is 15 percent, whereas it is 5 percent for $\mathrm{M} 2$ and 4 percent for $\mathrm{M} 3$, meaning that long-run cointegration information obtained from Johansen test is confirmed by the VECM analysis. Direction of causality from credits to money supply provides evidence that money is endogenous and that CBRT fully accomodates the demand for reserves by banks. 
Baştav, L. (2021). Endogenous money supply: Turkish economy (2011-2018).

Fiscaoeconomia, 5(2), 595-610. doi: 10.25295/fsecon.891839

Table 4: Vector Error Correction Model Results - Long Run

\begin{tabular}{|c|c|c|c|c|c|}
\hline \multicolumn{4}{|c|}{ Long Run Coefficients } & \multicolumn{2}{|c|}{ Long Run } \\
\hline DV & INDV & Lag & ECT & $\begin{array}{c}\text { t-Stat } \\
\text { (probability) }\end{array}$ & Result \\
\hline LMB & LCR & 1 & -0.15 & $\begin{array}{c}-2.13 \\
(0.04) \\
\end{array}$ & LCR $\rightarrow$ LMB \\
\hline LCR & LMB & 1 & 0.02 & $\begin{array}{c}3.95 \\
(0.00) \\
\end{array}$ & - \\
\hline LM2 & LCR & 1 & -0.05 & $\begin{array}{c}-1.99 \\
(0.049)\end{array}$ & LCR $\rightarrow$ LM2 \\
\hline LCR & LM2 & 1 & 0.03 & $\begin{array}{c}1.26 \\
(0.21) \\
\end{array}$ & - \\
\hline LM3 & LCR & 1 & -0.04 & $\begin{array}{l}-1.76 \\
(0.08)\end{array}$ & LCR $\rightarrow$ LM3 \\
\hline LCR & LM3 & 1 & 0.03 & $\begin{array}{c}1.36 \\
(0.18) \\
\end{array}$ & - \\
\hline
\end{tabular}

At the next step we search for short-run causality between variables by VECM equations. As per table results there is short-run causality from credits to $M 2$ as well as from credits to $M 3$ with a lag of one period i.e. one month in Turkey during the time spanning the period between 2011-2018. One period lagged credits affect M2 positively, with a statistically significant coefficient in the next period. Similarly rise in total private sector credits will raise $\mathrm{M} 3$ in the following month. Money is causally related to credits both in the short-run and long-run for $\mathrm{M} 2$ and $\mathrm{M} 3$ and only in the long-run for the monetary base. Long-run deviations from equilibrium will be corrected by 15, 5 and 4 percent each month for the monetary base, M2 and $\mathrm{M} 3$ respectively. 
Baştav, L. (2021). Endogenous money supply: Turkish economy (2011-2018).

Fiscaoeconomia, 5(2), 595-610. doi: 10.25295/fsecon.891839

Table 5: Vector Error Correction Model Results - Short Run

\begin{tabular}{|c|c|c|c|c|c|}
\hline \multicolumn{4}{|c|}{ Short Run Coefficients } & \multicolumn{2}{|c|}{ Short Run } \\
\hline DV & INDV & Lag & Coefficient & $\begin{array}{c}\text { t-Stat } \\
\text { (probability) }\end{array}$ & Result \\
\hline LMB & LCR & 1 & 1.38 & $\begin{array}{c}0.70 \\
(0.48)\end{array}$ & - \\
\hline LCR & LMB & 1 & -0.006 & $\begin{array}{l}-1.09 \\
(0.28)\end{array}$ & - \\
\hline LM2 & LCR & 1 & 0.34 & $\begin{array}{c}1.72 \\
(0.09)\end{array}$ & LCR $\rightarrow$ LM2 \\
\hline LCR & LM2 & 1 & -0.20 & $\begin{array}{l}-1.56 \\
(0.12)\end{array}$ & - \\
\hline LM3 & LCR & 1 & 0.33 & $\begin{array}{c}1.65 \\
(0.10)\end{array}$ & $\mathrm{LCR} \rightarrow \mathrm{LM} 3$ \\
\hline LCR & LM3 & 1 & -0.19 & $\begin{array}{l}-1.45 \\
(0.15)\end{array}$ & - \\
\hline
\end{tabular}

Finally, we estimate a four variate VAR model in order to check robustness of results of the analysis on money supply endogeneity. In order to check causality between variables we add consumer price index into the model and estimate Toda Yamamoto VAR equations for $L M B$, $L M 2, L C R, \angle C P I$ and $L M B, L M 3, L C R, L C P I$ respectively. Results follow in Tables 6 and 7 below.

\subsection{Causality with VAR Based Toda-Yamamoto Model}

Money creation mechanism in Turkey has been investigated by Johansen and VECM equations which have provided us with information of cointegration and long-run/short-run causality. Toda and Yamamoto (1995) have offered a method of augmented VAR to specify causality between the variables, providing asymptotic distribution of the MWald statistic, which is robust independent of the level of integration and cointegration of the variables in question. ${ }^{2}$ The method can be utilized independent of the unit root tests as well as cointegration preconditions between variables. At the first step we find order of integration of each time series, getting the maximum order $\left(d_{\max }\right)$ whenever order of integration is different. Following an optimal VAR of order $\mathrm{k}^{3}$ at the series level is specified regardless of level of integration of the variables. At the third step we estimate the augmented VAR with $\left(k+d_{\max }\right)$ order; and apply the Granger non-causality tests, with block exogeneity MWald statistics of $X^{2}$ distribution.

\footnotetext{
2 Thus there is no information loss by taking differences of variables for Granger causality, and/or cointegration tests.

${ }^{3} \mathrm{k}$ is found out by optimum lag selection with one of the AIC, SIC or HQ etc criteria of the VAR model.
} 


$$
\left[\begin{array}{l}
\operatorname{lmon}_{t} \\
l m 2_{t} \\
l c r_{t} \\
l c p i_{t}
\end{array}\right]=\beta_{0}+\sum_{i=1}^{k}\left(\beta_{i}\left[\begin{array}{l}
\operatorname{lmon}_{t-i} \\
l m 2_{t-i} \\
l c r_{t-i} \\
l c p i_{t-i}
\end{array}\right]\right)+\sum_{j=k+1}^{k+d_{\max }}\left(\beta_{j}\left[\begin{array}{l}
\operatorname{lmon}_{t-j} \\
l m 2_{t-j} \\
l c r_{t-j} \\
l c p i_{t-j}
\end{array}\right]\right)+\left[\begin{array}{l}
\epsilon_{l m o n t} \\
\epsilon_{l m 2_{t}} \\
\epsilon_{l c r_{t}} \\
\epsilon_{l c p i_{t}}
\end{array}\right]
$$

The equation system estimated is given as in (2) above where $\beta_{0}$ is $4 \times 1$ vector, $\beta$ and $\beta$ j are $4 X 4$ coefficient matrices and $\in$ is $4 X 1$ vector of the error term. For the TY model with LMB, LM2, LCR, LCPI, highest level of integration is I(1) and optimum VAR lag length is $k=1{ }^{4}$. Thereby $\operatorname{VAR}(2)$ is estimated for Toda Yamamoto where the model is free of autocorrelation and heteroscadasticity and residuals are normally distributed by Jarque Berra test. Results for causality are provided in Table 6 below.

Table 6: Toda-Yamamoto No-Causality Test Results (LMB, LM2, LCR, LCPI)

\begin{tabular}{|c|c|c|c|c|c|}
\hline $\begin{array}{l}\text { Dependent } \\
\text { Variable }\end{array}$ & $\operatorname{Lag}(k)$ & $\operatorname{Lag}\left(\mathbf{k}+\mathbf{d}_{\max }\right)$ & Chi-sq & Prob. & $\begin{array}{c}\text { Direction of } \\
\text { Causality }\end{array}$ \\
\hline \multicolumn{6}{|c|}{ (LMB)Mon Base } \\
\hline LM2 & 1 & $1+1$ & 1.70 & 0.43 & $\mathrm{LM} 2 \neq \mathrm{LMB}$ \\
\hline LCR & 1 & $1+1$ & 2.07 & 0.35 & $\mathrm{LCR} \neq \mathrm{LMB}$ \\
\hline LCPI & 1 & $1+1$ & 0.92 & 0.63 & $\mathrm{LCPI} \neq \mathrm{LMB}$ \\
\hline \multicolumn{6}{|l|}{ (LM2) M2 } \\
\hline LMB & 1 & $1+1$ & 4.04 & 0.13 & $\mathrm{LMB} \neq \mathrm{LM} 2$ \\
\hline LCR & 1 & $1+1$ & 3.39 & 0.18 & $\mathrm{LCR} \neq \mathrm{LM} 2$ \\
\hline LCPI & 1 & $1+1$ & 5.58 & 0.06 & $\mathrm{LCPI} \rightarrow \mathrm{LM} 2$ \\
\hline \multicolumn{6}{|c|}{ (LCR) Credits } \\
\hline LMB & 1 & $1+1$ & 11.02 & 0.004 & LMB $\rightarrow$ LCR \\
\hline LM2 & 1 & $1+1$ & 0.21 & 0.90 & $\mathrm{LM} 2 \neq \mathrm{LCR}$ \\
\hline LCPI & 1 & $1+1$ & 9.04 & 0.01 & $\mathrm{LCPI} \rightarrow \mathrm{LCR}$ \\
\hline \multicolumn{6}{|c|}{ (LCPI) Inflation } \\
\hline LMB & 1 & $1+1$ & 0.16 & 0.93 & $L M B \neq L C P I$ \\
\hline LM2 & 1 & $1+1$ & 3.04 & 0.22 & $\mathrm{LM} 2 \neq \mathrm{LCPI}$ \\
\hline LCR & 1 & $1+1$ & 7.54 & 0.02 & $\mathrm{LCR} \rightarrow \mathrm{LCPI}$ \\
\hline
\end{tabular}

Results reveal causality from total private sector credits to money supply aggregates $M 2$ and $\mathrm{M} 3$ as assumed by the Post-Keynesian thought. Findings support previous results from cointegration and VECM analysis that causality runs from credits to money supply and that money supply is endogenous. In the model with LMB, LM2, LCR, LCPI causality goes directly from credits to inflation and from inflation to money supply $M 2$. There is also reverse causality from inflation to credits. Monetary base also directy effects total credits. Inclusion of cpi into the analysis has provided the information that rise/fall in money supply operates through changes in the price level.

\footnotetext{
${ }^{4}$ By the minimum information criteria SC and $\mathrm{HQ}$.
} 
$\mathrm{LCR} \leftrightarrow \mathrm{LCPI} \rightarrow \mathrm{LM} 2$

$\uparrow$

LMB

In the second model with LMB, LM3, LCR, LCPI, highest level of integration is I(1) and optimum VAR lag length is $k=2^{5}$ as a result of which Toda Yamamoto VAR(3) is estimated. The model is free of autocorrelation and heteroscadasticity. Estimation results with LMB, LM3, LCR, LCPI provide similar information of direct causality from credits to inflation and from inflation to M3. Bivariate causality from inflation to credits at five percent level of significance stil exists. This time there is also reverse causality from $\mathrm{M} 3$ to credits indirectly through the cpi inflation. The causality from broad money supply $M 3$ to credits points at the liquidity effect in the economy. Direct effect from monetary base to credits at five percent level of significance points at the dominant liquidity effect in the economy.

$\mathrm{LCR} \leftrightarrow \mathrm{LCPI} \leftrightarrow \mathrm{LM} 3$

$\uparrow$

LMB

Table 7: Toda-Yamamoto No-Causality Test Results (LMB, LM3, LCR, LCPI)

\begin{tabular}{|c|c|c|c|c|c|}
\hline $\begin{array}{l}\text { Dependent } \\
\text { Variable }\end{array}$ & $\operatorname{Lag}(k)$ & $\operatorname{Lag}\left(\mathbf{k}+d_{\max }\right)$ & Chi-sq & Prob. & $\begin{array}{c}\text { Direction of } \\
\text { Causality }\end{array}$ \\
\hline \multicolumn{6}{|c|}{ (LMB)Mon Base } \\
\hline LM3 & 2 & $2+1$ & 0.52 & 0.91 & LM3 $\neq \mathrm{LMB}$ \\
\hline LCR & 2 & $2+1$ & 2.19 & 0.53 & $\mathrm{LCR} \neq \mathrm{LMB}$ \\
\hline LCPI & 2 & $2+1$ & 0.90 & 0.82 & $\mathrm{LCP} \mid \neq \mathrm{LMB}$ \\
\hline \multicolumn{6}{|c|}{$\begin{array}{l}\text { (LM3) Money } \\
\text { Supply }\end{array}$} \\
\hline LMB & 2 & $2+1$ & 3.61 & 0.31 & $\mathrm{LMB} \neq \mathrm{M} 3$ \\
\hline LCR & 2 & $2+1$ & 2.90 & 0.41 & $\mathrm{LCR} \neq \mathrm{M} 3$ \\
\hline LCPI & 2 & $2+1$ & 6.35 & 0.096 & $\mathrm{LCPI} \rightarrow \mathrm{M} 3$ \\
\hline \multicolumn{6}{|c|}{ (LCR) Credits } \\
\hline LMB & 2 & $2+1$ & 8.74 & 0.03 & LMB $\rightarrow$ LCR \\
\hline LM3 & 2 & $2+1$ & 1.44 & 0.70 & $\mathrm{LM} 3 \neq \mathrm{LCR}$ \\
\hline LCPI & 2 & $2+1$ & 10.20 & 0.02 & LCPI $\rightarrow$ LCR \\
\hline \multicolumn{6}{|c|}{ (LCPI) Inflation } \\
\hline LMB & 2 & $2+1$ & 0.60 & 0.90 & $\mathrm{LMB} \neq \mathrm{LCPI}$ \\
\hline LM3 & 2 & $2+1$ & 7.89 & 0.05 & LM3 $\rightarrow$ LCPI \\
\hline LCR & 2 & $2+1$ & 11.21 & 0.01 & LCR $\rightarrow$ LCPI \\
\hline
\end{tabular}

\footnotetext{
${ }^{5}$ By the minimum information criteria AIC, FPE and LR.
} 


\section{Findings and Conclusions:}

Endogenous money hypothesis of the Post Keynesian economics incurs a relation between credit demand in the economy and money creation. Recently this hypothesis has received much attention and researchers have conducted numerous studies, results of which mostly support endogenous money for different countries. In this study we have tested endogenous money hypothesis for the Turkish economy for the years 2011 to 2018 with the monetary base, M2, M3 and total credits. Johansen cointegration tests have provided evidence in favor of long run relationship between money supply and total credits, which is further supported by the VECM analysis with additional information about causality from credits to money. Results of the VECM analysis reveal there is both short-run and long-run causality from credits to $\mathrm{M} 2$ and $\mathrm{M} 3$ and only long-run causality from credits to the monetary base.

The study has further been extended with inclusion of cpi inflation to check robustness of results from cointegration and VECM. A four variate Toda Yamamoto model has been conducted with extended lag length, results of which support the endonenous money hypothesis that there is causality from bank loans to money supply via inflation. While this causality is valid for $\mathrm{M} 2$ and $\mathrm{M} 3$, there is also reverse causality from $\mathrm{M} 3$ to bank loans.

Results reveal endogenous money in Turkey determined by credit demand of firms and households. Results support accommodative endogenous money hypothesis that central banks create the needed liquidity to meet reserve requirement of banks. Presence of reverse causality from M3 to credits also implies relevance of the liquidity preference approach. The two approaches explain behavior of money creation in Turkey and are complementary. Results are in line with previous findings of Yurtkur (2019) and Güney and Çepni (2016) who have both detected the accommodative and liquidity preference mechanisms in endogeneous money creation.

Within the framework monetary authorities should pay particular attention to credit demand behavior, and to independent liquidity preferences of economic units in conducting monetary policy, rather than treating the money supply as an exogenous policy instrument.

\section{References}

Arestis, P. (1987/88). "The Credit Segment of a UK Post Keynesian Model" Journal of Post Keynesian Economics, V. 10, N. 2, 250-69.

Arestis, P., Mariscal, I.B.F. (1995). "The Endogenous Money Stock: Empirical Observations from the United Kingdom", Journal of Post Keynesian Economics, V. 17, N. 4, 545-559.

Aybar, S., Harris, L. (1988). “Credibility Models of Central Bank Independence and the Case of Turkey", METU Studies in Development, V. 25, N. 4, 535-558.

Badarudin Z.E. et al. (2013). "Post-Keynesian Money Endogeneity Evidence in G-7 Economies", Journal of International Money and Finance, 33, 146-162.

Cifter, A., Özün A. (2007). "The Monetary Transmission Mechanism in the New Economy: Evidence from Turkey (1997-2006)", South East European Journal of Economics and Business, 2, 15-24. 
Baştav, L. (2021). Endogenous money supply: Turkish economy (2011-2018).

Fiscaoeconomia, 5(2), 595-610. doi: 10.25295/fsecon.891839

Çavuşoğlu, A. T. (2003). "The Endogenous Money Growth: An Outcome of High Budget Deficits in Turkey", HÜ iktisadi ve Idari Bilimler Fakültesi Dergisi, 21(1), 111-127.

Dişyatat, P. (2008). "Monetary Policy Implementation: Misconceptions and Their Consequences", BIS Working Papers, No.269.

Fontana, G. (2003). "Post Keynesian Approaches to Endogenous Money: A Time Framework Explanation", Review of Political Economy, 291-314.

Güney, I. E., Çepni, O. (2016). “Endogeneity of Money Supply: Evidence from Turkey”, TCMB Reseach Notes in Economics, Nbr 2016-19, 1-12.

Howells, P. (2006). "The Endogeneity of Money: Empirical Evidence", in P. Arestis and M. Sawyer (Eds.). A Handbook of Alternative Monetary Economics (pp. 52-68). Cheltenham: Edward Elgar

(1999). "The Source of Endogenous Money", Economic Issues, V. 4, N 1, 101-112.

(1995), "The Demand for Endogenous Money", Journal of Post Keynesian Economics 18(1), Fall 1995, 89-106

Howells, P., Hussein, K. (1998). "The Endogeneity of Money: Evidence from G7" Scottish Journal of Political Economy, V. 45, N. 3, 329-40.

Howells, P., Mariscal, I.B.F. (1992). "An Explanation for the Recent Behavior of Income and Transaction Velocities in the United Kingdom", Journal of Post Keynesian Economics, V. 14, N. 3, 367-88.

Işık, S. (2000). Para Arzının Endojenliği Tartışması: Türkiye Örneği. Doktora Tezi, Ankara: Hacettepe Üniversitesi Sosyal Bilimler Enstitüsü.

Işık, S., Kahyaoğlu H. (2011). "The Endogenous Money Hypothesis: Some Evidence from Turkey (1987-2007)", Journal of Money, Investment and Banking, 19, 61-71.

Işık, S., Alkın, H., Uluğ, M. (2018). “Avrupa Birliği Üyesi 13 Ülkede Post-Keynesyen Para Arzının İçselliği Hipotezinin Test Edilmesi", Kafkas Üniversitesi Iktisadi ve Idari Bilimler Fakültesi Dergisi, 9(17), 1-20.

Incekara, A., Amanov, A. (2017). "Optimal Instrument Selection in Monetary Policy: Endogeneity of Money Supply", Journal of Business Economics and Finance, Vol (6), Iss 2, 61-69.

Kaldor, N. (1989). "Origins of the New Monetarism”, In F. Targetti, F. Thirwal and A. P. (Eds.), Futher Essays on Economic Theory and Policy (pp. 160-177). New York: Holmes-Meier, (1985). The Source of Monetarism. 2nd edn., Oxford: Oxford University Press, Oxford.

(1987). "The Role of Commodity Prices in Economic Recovery", World Development, Vol 15, Iss 5, May 1987, 551-558 
Baştav, L. (2021). Endogenous money supply: Turkish economy (2011-2018).

Fiscaoeconomia, 5(2), 595-610. doi: 10.25295/fsecon.891839

Karabulut, G. (2005). "Paranın Endojenliği ve Türkiye Örneği”, Yönetim/Istanbul Üniversitesi İsletme Fakültesi İşletme iktisadı Enstitüsü Dergisi, V. 16, N. 51, 25-31.

Lavoie, M. (2005). "Monetary Base Endogeneity and the New Procedures Of The Asset-Based Canadian And American Monetary Systems", Journal of Post Keynesian Economics, 27(4), 689-708.

(1992). Foundations of Post-Keynesian Economics. Aldershot: Edward Elgar.

Minsky, H.P. (1982). Can 'It' Happen Again? Essays on Instability and Finance. New York: M. E. Sharpe.

Moore, B. J. (1989). "The Endogeneity of Credit Money", Review of Political Economy, 1(1), 6593.

(1983). "Unpacking the Post Keynesian Black Box: Bank Lending and the Money Supply", Journal of Post Keynesian Economics, V. 5, N. 4., 537-556.

(1979). "The Endogenous Money Stock", Journal of Post Keynesian Economics, V. 2, N. $1,49-70$.

Moore, B. J., Threadgold, A. R. (1985). "Corporate Bank Borrowing in the UK, 1965-1981", Economica, V. 52, N. Feb, 65-78.

Nayan, S., Kadir, N., Abdullah M.S. and Ahmad, M. (2013). "Post Keynesian Endogeneity of Money Supply: Panel Evidence", Procedia Economics and Finance, 7, 48-54.

Özgür, G. (2011). “Türkiye Ekonomisinde Para Arzının İçsel Süreci”, Ekonomik Yaklaşım, 22(78), 67-90.

Palacio-Vera, A. (2001). "The Endogenous Money Hypothesis: Some Evidence from Spain (1987-98)", Journal of Post Keynesian Economics, V.23, N. 3, 509-526.

Palley, T. (1991). "The Endeogenous Money Supply: Consensus and Disagreement", Journal of Post Keynesian Economics, 13(3), 397-403.

Panagopoulos, Y., Spiliotis, A. (1998). “The Determinants of Commercial Banks' Lending Behavior: Some Evidence for Greece", Journal of Post Keynesian Economics, 20(4), 649672.

Pollin, R. (1991). "Two Theories of Money Supply Endogeneity: Some Empirical Evidence", Journal of Post Keynesian Economics, V. 13, N. 3, 366-96.

Rogers, C. (1989). "Money, Interest and Capital: A Study in the Foundations of Monetary Theory". Cambridge: Cambridge University Press.

Tayyar, A. E. (2017). "Political Exchange Rate Fluctuations Specific to Fixed Exchange Rate

Regimes: A Case Study on Turkey", Annals of the Constantin Brancusi University of Targu Jiu, Economy Series, Issue 2, 4-14.

Tobin, J. (1971). Essays in Economics: Macroeconomics. Chicago: Markham.

Toda, H.Y., Yamamoto, T. (1995). "Statistical Inference in Vector Autoregressions with Possibly Integrated Processes", Journal of Econometrics. 66, pp.225-250. 
Baştav, L. (2021). Endogenous money supply: Turkish economy (2011-2018).

Fiscaoeconomia, 5(2), 595-610. doi: 10.25295/fsecon.891839

Vera, A. P. (2001). "The Endogenous Money Hypothesis: Some Evidence from Spain (19871998)", Journal of Post Keynesian Economics, 23(3), 509-526.

Wray, L. R. (1992). "Alternative Theories of the Rate of Interest", Cambridge Journal of Economics, Vol. 16, Issue 1, 69-89.

(1990). Money and Credit in Capitalist Economies: The Endogenous Money Approach", " Aldershot, Edward Elgar

Yurtkur, A.K. (2019). Para Arzının İçselliği Hipotezi: Türkiye için Ampirik Bir Analiz (2006-2018), International Journal of Economic and Administrative Studies, (24).

Ethics Statement: The authors declare that ethical rules are followed in all preparation processes of this study. In case of detection of a contrary situation, Fiscaoeconomia has no responsibility and all responsibility belongs to the authors of the study.

Acknowledgement: Assoc. Prof. Dr. Atilla Gökçe, for his valuable views on the econometric models and methods.

Etik Beyanı: Bu çalışmanın tüm hazırlanma süreçlerinde etik kurallara uyulduğunu yazarlar beyan eder. Aksi bir durumun tespiti halinde Fiscaoeconomia Dergisinin hiçbir sorumluluğu olmayıp, tüm sorumluluk çalışmanın yazarlarına aittir.

Teşekkür: Doç. Dr Atilla Gökçe, ekonometrik yöntemlerle ilgili değerli görüşleri için. 